\section{Om de store biologiske sammenhenger}

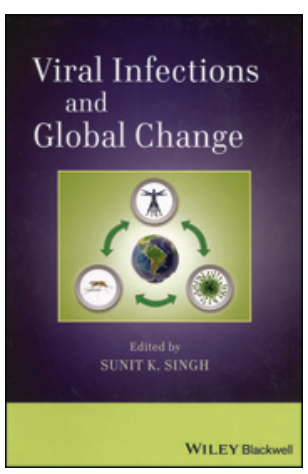

Sunit K. Singh, red.

Viral infections and global change

628 s, tab, ill. Chichester: Wiley-Blackwell,

2014. Pris GBP 100

ISBN 978-1-118-29787-2

Formålet med denne utgivelsen er å vise hvordan globale endringer, ikke minst klimaendringer, kan påvirke geografisk fordeling og spredningsmønster for vektorbårne og zoonotiske virus. Slike virus forårsaker økende helseproblemer hos både mennesker og dyr. Imidlertid er det ikke bare endringer i gjennomsnittstemperatur og luftfuktighet som påvirker denne utviklingen; også endringer på områder som menneskelig atferd, arealbruk, industriell virksomhet, migrasjon og helsepolitikk utfordrer tradisjonelle økosystemer.

Boken er omfattende, og den angitte målgruppen er også stor. Ifølge redaktøren henvender man seg til alle som er interessert $i$ virussykdommer. Særlig nevnes virologer, klinikere, økologer samt studenter og forskere innen medisin, veterinærmedisin og biologi. Også den opplyste allmennhet antas ha glede av denne antologien. Med omkring 80 velrennomerte bidragsytere fra en rekke land må boken ha gitt redaktøren store utfordringer utover faglig tilrettelegging.

31 kapitler er fordelt på to hoveddeler. Den første presenterer generelle aspekter ved vektorbårne og zoonotiske virus i forbindelse med globale endringer, for eksempel hvordan klimatisk utvikling, avskoging og urbanisering påvirker vektorer og vektorbårne virus, og hvordan virale zoonoser påvirkes av menneskelig atferd. I denne delen beskrives også overvåkingssystemer og prediktiv modellering for virale sykdommer, utviklingen innen diagnostisk virologi, virusbasert bioterrorisme samt mekanismer for utvikling av nye virus. Den andre delen presenterer klimatiske, miljømessige og sosiologiske aspekter ved spesifikke agens som influensavirus, coronavirus, arenavirus, astrovirus, norovirus og flåttbårne virus.

Jeg er imponert over bokens holistiske tilnærming og har sans for ideen om at vår helse i siste instans er avhengig av helsen til alle komponentene $\mathrm{i}$ vårt økosystem. Boken er velredigert, tabeller og illustrasjoner er mange og gode, og litteraturhenvisningene er omfattende. Trolig er det uunngåelig at noen kapitler gir delvis overlappende informasjon, og at det empiriske grunnlaget for spådommer om den epidemiologiske utviklingen iblant er spinkelt.

Deler av boken kan synes lite relevant for norske forhold, men verden skrumper, og informasjonen om agens som ebolavirus, sars-CoV, denguevirus og TBE-virus er høyst aktuell også hos oss. På grunn av sin detaljrike, strikt vitenskapelige fremstilling er boken ikke spesielt lettlest, men redaktøren kan ha rett i at innholdet er viktig for alle med interesse for makro- og mikroorganismenes komplekse samspill. Og for dem som daglig arbeider med medisinsk virologi, infeksjonsmedisin, internasjonal helse og medisinsk økologi, er denne utgivelsen utvilsomt en oppdatert og viktig referanse. Men noen bestselger blant studenter og den opplyste allmennhet blir denne omfattende antologien neppe.

Bjarne Bjorvatn

Professor emeritus, Senter for internasjonal helse og Gades Institutt Universitetet i Bergen

\section{Medisinen er død - leve medisinen!}

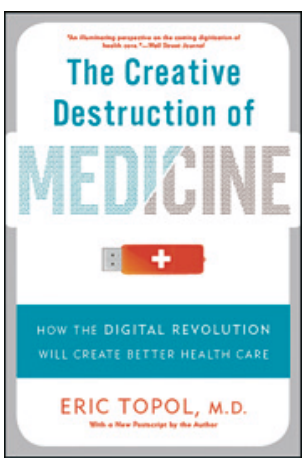

Eric Topol

The creative destruction of medicine

How the digital revolution will create better health care. 303 s. New York: Basic Books, 2012. USD 18

ISBN 978-0-465-06183-9

I sin nåværende form har medisinen utspilt sin rolle. Men det er håp i de digitale sfærer. Dette er hovedbudskapet i denne tankevekkende og provoserende boken skrevet av en av verdens mest omtalte hjerteog genforskere. (Topol var en av de første som påpekte faren for bivirkninger ved Vioxx). Boken henvender seg til den helseinteresserte allmennhet. Den er fullpakket med medisinske fakta forklart på en forståelig måte. Topol kritiserer medisinsk praksis. Diagnostikken er for upresis, og behandlingen lite virksom. Han vil bort fra forskning basert på hypoteser, populasjoner og faglige premisser. Det som vil redde medisinen, er en individorientert forening av genomikk, metabolikk, proteomikk, informasjonsteknologi og smarttelefoner. Det må bli slutt på store studier som viser marginale gevinster for noen få. Målrettet personorientert forskning som gir merkbare resultater, er det som må til.

Der kritikken av dagens medisin er målrettet, velinformert og treffsikker, er fremtidsvyene noe mer svevende. Selv om Topol er svært godt orientert om nyere såkalt «omisk» forskning, og også kan vise til en rekke konkrete resultater innen farmakogenomikk og smarttelefoni, blir det uklart hvordan den store syntesen av dette skal skape et bedre helsevesen. Ved kontinuerlig å samle helseinformasjon fra store deler av befolkningen, fra unnfangelse til grav, vil man få nok data til å revolusjonere forskning og klinikk. Topol mener man vil unngå storebror-ser-deg-problemet fordi vi alle vil bidra med våre data i en stor dugnad. Slik Wikipedia bidrar til felles kunnskap, vil vi få en allmenn helsekunnskapsbase. En ny individbasert helseaktivisme vil erstatte dagens populasjonsbaserte, hegemoniske medisin. Det er fristende å avfeie Topol med at han er en virkelighetsfjern visjonsakrobat, men som direktør i Scribbs Research Institute i California forsker han daglig på løsningene han prediker. Om resultatene så langt har destruert dagens medisin, er heller tvilsomt, men kreativt er det i hvert fall. Uttrykket «kreativ destruksjon» i tittelen stammer for øvrig fra økonomene Werner Sombart og Joseph Schumpeter, og brukes for å vise til innovasjoner som totalt forandret verden.

For mange vil nok denne boken fremstå som utopisk og spekulativ, men for den som funderer over hva medisinen er og hva den bør bli, vil den kunne være en rik kilde til refleksjon.

\section{Bjørn Hofmann}

Forsker, Hanover, New Hampshire, USA 